\title{
Multiple Points of Contact: Promoting Rural Postsecondary Preparation through School-Community Partnerships
}

\author{
Nathan F. Alleman \\ Baylor University \\ L. Neal Holly \\ West Virginia Higher Education Policy Commission
}

\begin{abstract}
Formal and informal partnerships between rural schools and their communities can provide a wide range of supports for all students, but particularly those from low-income families. In this analysis of six small rural school districts in Virginia we show how the broad participation of community groups and individuals supports academic achievement as well as preparation and aspirations for postsecondary education. Results demonstrate that schoolcommunity partnerships provide multiple points of contact for students that buttress the efforts of school personnel by extended educational opportunities outside the classroom and by meeting the needs of low-income students when parents and teachers are unable to do so.
\end{abstract}

\section{Key Words: Rural, college preparation, school-community partnerships.}

Within rural education research, postsecondary preparation and aspirations are most often linked to family and school factors, with community factors receiving minimal consideration (Apostal \& Biden, 1991; Chenoweth \& Galliher, 2004; McGrath, Swisher, Elder, \& Conger, 2001). Even studies that claim an "ecological" approach seldom consider the role of the local community in actively promoting educational values and outcomes (for example, Demi, Coleman-Jensen, \& Snyder, 2010; Roscigno \& Crowley, 2001). However, community members and resources can contribute to school success, creating learning opportunities grounded in local culture and heritage, for-profit and non-profit organizations, and natural and historical sites and resources (Bauch, 2004; Combs \& Bailey, 1992). Relationships established among students and community members through formal and informal learning and mentoring opportunities can confer social capital and provide information about pathways to careers and postsecondary education that might otherwise be unavailable, in particular to low-income students (Bauch, 2004; Beaulieu \& Israel, 2005; Israel, Beaulieu, \& Hartless, 2001). Also, schoolcommunity connections provide a sense of place and identity that provide stability and continuity despite economic stressors (Khattari, Riley, \& Kane, 1997). Although evidence supports the importance of community contributions to school success (Combs \& Bailey, 1992; Decker \& Decker, 2003; Sanders, 2006; Khattari, Riley, \& Kane, 1997) a full analysis of the ways that school-community partnerships promote rural students' educational attainment and postsecondary aspirations has not been conducted. In this study we examine six small, rural, high poverty school districts in Virginia. The guiding question for this study was, in what ways to formal and informal school-community partnerships, individually and as a group, promote postsecondary readiness and ambition among low-income students?

\section{Review of Literature}

To frame the study we began with a review of literature focusing on four inter-related sub-topics: ways that rural areas and schools benefit one another, school-level and community-level factors that influence the success of rural students, formal and informal school-community partnerships, and postsecondary access in the rural context.

\section{School and Community-Level Reciprocal Benefits}

Prior research demonstrates the potential - if not actual - beneficial symbiosis between rural localities and their schools. For example, public K-12

education can be a source of local revitalization, workforce preparation, community leadership, and economic vitality (Combs \& Bailey, 1992; Harmon \& Schafft, 2009; Lyson, 2002). Similarly, rural communities can contribute to the success of schools in a variety of ways. Communities may provide social capital through mentoring and positive influence relationships (Isernhagen, 2010; Israel, Beaulieu, \& Hartless, 2001; Lerner, 2005); in addition, they may offer formal and informal job shadowing, apprenticeship, and internship opportunities (Bauch, 2004; Khattari, Riley, \& Kane, 
1997), and they generally reinforce the importance of academic success among individual students and within the community at large (Harmon \& Schafft, 2009; Stockard \& Mayberry, 1992).

\section{School-Level and Community-Level Factors}

Typically, studies of rural school success focus on school-level factors such as collaborative leadership (Chance, Work, \& Larchick, 1991), teacher morale (Battistich, et al., 1995), and studentcentered planning (Chance \& Segura, 2009). Although school factors may have the greatest direct impact on student achievement, sub-elements of the community also play important roles (Bauch, 2004; Combs \& Bailey, 1992; Irvin et al., 2010; Khattari, Riley, \& Kane, 1997). Bauch (2004) identifies six types of family-school connections that matter for school success: social capital, sense of place, parental involvement, church ties, school-business-agency relationships, and community as a curricular resource. Although locally-based civic entities (churches, businesses, and agencies) are important elements for rural educational success, Bauch focuses on the implications of these school-community ties for educational leadership and does not fully explore the full range of residents and groups who promote student success. Researchers have also focused on particular community groups, such as churches, that often play important roles in reinforcing academic values, providing accountability, tutoring, and mentoring, and creating forums where educationrelated issues can be discussed (Irvin, et al., 2010; Stanton-Salazar \& Spina, 2003; Timmermans \& Booker, 2006).

\section{Formal and Informal School-Community Partnerships}

Research on school-community partnerships advances the importance of the involvement of local organizations and businesses through formalized agreements with specific measurable objectives (Decker, Decker, \& Brown, 2007; Jones \& Maloy, 1988; Sanders, 2006; Wright, Stegelin, \& Hartle, 2007). Agreements between schools and resourceproviding entities can take many forms and serve many goals, based on the resources of the partnering group, the longevity and frequency of the relationship, the needs and vision of the school, and other factors (Sanders, 2006). In one of the few school-community partnership studies set in a rural context, Combs \& Bailey (1992), found that despite a dearth of local entities available for such alliances, even a small number cooperative relationships of this type can positively impact school climate, produce a stronger more visible link between school and community, and contribute to community empowerment by mobilizing local resources to help students think about and work at pressing local problems. Combs \& Bailey used the term "alliances" to describe positive relationships between school and community. Other researchers de-emphasize these formal agreements in favor of shared commitments to and responsibilities for creating a local environment that is student-centered and broadly pro-educational (Decker \& Decker, 2003). In combination, these two approaches highlight the value of particular targeted agreements as well as large-scale and broad-based support across the community. However, studies of either type seldom consider the link between these programs and supports and preparation for postsecondary education.

\section{Postsecondary Access in the Rural Context}

Educational researchers have highlighted the complex and at times contradictory positions of postsecondary education within rural communities (Chenoweth \& Galliher, 2004; Corbett, 2007; Gibbs, 1998; McGrath, Swisher, Elder, \& Conger, 2001). A segment of writers has criticized local education systems for serving as an exit point for "good" students from rural communities, making educators and postsecondary education either implicitly or explicitly responsible for "brain drain" and academic sorting by social class (Carr \& Kefalas, 2009; Corbett, 2007; Donaldson, 1986; Sherman \& Sage, 2011). However, McDonough (2004) suggests that place identity can bind even talented rural students to their communities in ways that inhibit postsecondary aspirations and attainment.

Other scholars have sounded a more hopeful note about the role of schools, educators, and education in rural areas (Gibbs \& Cromartie, 1994; Kelly, 2009; Woods, Doeksen, \& Clair, 2005). Contrary to Carr \& Kafelas (2009), Petrin, Schafft, and Meece (2012) found that local economic context, rather than the direct influence of educators, contributed most to the out-migration of rural youth. Even among those planning to depart, a noticeable cohort, known as Returners, shaped their collegiate plans to maximize the possibility of returning to their home communities. Rather than contributing to permanent departure, discussions with adults about future plans reinforced aspirations to remain. Other researchers (Gibbs \& Cromartie, 2004; Kelly, 2009; Wright, 2012) develop this point further, arguing that returning students are better equipped to serve the needs of their rural communities because of their broad experiences. 
Nevertheless, the role of formal and informal school-community partnerships in post-secondary preparation and aspiration has not been well researched, in part because school-community partnership literature tends to focus on $\mathrm{K}-12$ success and not the implications of these relationships for further education. Although we acknowledge that education plays a complex and at times a negative role in small rural communities, we also observe through this study and the existing literature (Petrin, Schafft, \& Meece, 2012) that improved opportunity for all students through high quality education maximizes life choices for individuals and may offer a key local resource for future community vitality.

\section{Methods}

This study employed a mixed-methods design that combined the in-depth personal perspectives of individual participant interviews with the broad contextual and demographic data derived from a teacher survey instrument (Creswell, 2008). This paper, however, reports only the qualitative data gained from participant interviews. Participating districts in the state of Virginia met three criteria: They had fewer than 2000 total students, K-12; they had above the state average of $37 \%$ Free and Reduced Price Meal (FRPM) program qualifiers, a proxy for low-income status (participant rates varied from about $55 \%$ to about $75 \%$ ), and they were located in rural areas of the state, determined by relative population density and proximity to urban and metropolitan areas. Demographic, achievement, and migration data were also considered as the initial qualifying pool of 25 districts was reduced to six final participants. Our selections were made based on the most compelling combinations of academic successes, challenging demographics and other contextual variables (socio-economic status, migration, and other factors) so that our final selections were likely to reflect the variations found throughout the state. Participant districts all demonstrated points of academic success with lowincome students, although the challenges remaining varied by location. Six school districts, referred to here as Riverside, Heritage, Greenfield, Western, Timberland, and Twinsburg were invited and agreed to participate with approval from district administrators and school boards, though under the conditions of anonymity.

\section{Data Collection and Analysis Process}

Seventy-nine individuals across the six school districts participated in a semi-structured interview lasting between 45 and 90 minutes. Participants included school personnel, non-profit and public agency employees, civic and special interest group representatives, business leaders, higher education employees, education activists, religious leaders, and key local cultural informants. As is often the case in low-population rural areas, many of our participants filled several formal and informal roles in multiple categories. For example, one local business owner headed a non-profit community education foundation and had served on the school board. Potential interview participants were identified through a snowball process that began with the recommendations of school administrators who suggested individuals connected to community partnerships and to leadership positions in the community. From this list and our own research we invited participants to be part of the study. Each interview yielded additional participant recommendations, broadening the scope and input. All participants were advised about the nature of the study, the extent of their participation, and protections of anonymity and confidentiality.

All interviews were transcribed verbatim and entered into Nvivo 9 ethnographic software for analysis. Through an emergent coding process we organized and analyzed interview transcripts, beginning with five themes (school-community partnerships, school-community topics, higher education topics, school topics, and local pressing local issues). These pre-established focal topics guided initial coding but we also maintained a pool of outlier themes so that new and contradictory patterns could emerge, challenge, and become part of our final analysis. From these initial codes and our extensive field notes we developed a set of preliminary themes and findings per district that were member-checked for accuracy with a selection of participants before identifying conclusions for this report. For example, in Timberland School District we identified nine major themes: economic context, social context, existing partnerships, community attitudes toward college going, school division attitudes and behaviors related to achievement and college going, the role of parents, the role of facilities, non-school educational resources, and programs that support post-secondary preparation. Funding for this study was provided by a federal College Access Challenge Grant held by the Commonwealth of Virginia and administered by SCHEV, the State Council of Higher Education for Virginia.

\section{Defining Terms}

In this study we elected to use the term "schoolcommunity partnership" since it relates to an 
established sub-field of educational research. Based on Sanders' (2006) definition, we define schoolcommunity partnerships as formal and informal mechanisms of support delivered by local persons or entities to promote schools' educational goals for student achievement and postsecondary aspirations. This definition is broadly inclusive of types of involvement (including material, social, economic, human, and knowledge-based resources) and sources of involvement so long as they have a legitimate local presence (businesses, non-profit organizations, public agencies, social organizations, and individuals).

The focus of this study is community supports for academic preparation that leads to postsecondary aspirations, access, and attainment. We intend "postsecondary education" to include any kind of post-high school education that results in a degree or professional credentials, including four-year, twoyear, technical, and other types of education.

\section{Findings}

Within the six case study districts, community partners contributed to the college readiness and ambition of students through services, activities, and social influence in five categories, from specific to general: by supporting academic and career success, providing information and advising, building aspirations and socialization to postsecondary education, creating a formal and informal economy of support, and developing a community commitment to the value of postsecondary education.

\section{Supporting Academic and Career Success}

For students to even consider postsecondary education, the barrier of qualification (taking the right courses and passing them) is the foremost hurdle that must be cleared (Cabrera \& La Nasa, 2001). Given the purposes of public education, the amount of direct instructional time allotted, and the extent of support resources and educational activities provided in and through the schools, teachers and school administrators are the primary points of contact for students' academic development. Nevertheless, in this study community individuals and groups reinforced and supplemented the efforts of school personnel in four ways. First, community partners provided academic tutoring in and outside of the school setting. In some cases tutoring was focused on a particular subject. In one district local bank employees provided regular math assistance to elementary students. Academic tutoring outside of the school context is a form of support that may go unnoticed by school personnel. In Twinsburg, a church held tutoring nights where retired and current educators helped students with math and reading skills and assignments over refreshments in the church basement. Tutoring was offered by businesses, non-profits, public agencies, and faithbased groups across our six case districts. However, tutoring initiatives sometimes suffered from inconsistent delivery, both in quality and quantity.

Second, in-school academic efforts were often supported through donations of supplies and materials that improved the instructional process. In some cases donations were simply paper, pencils, and other basics otherwise available in minimal quantities (or not at all) due to budget cuts. In other cases teachers were able to write mini-grant requests to their community education foundation or another local partner for specific resources that would improve the delivery of course materials. For example, in Heritage School District a teacher received a mini-grant to make sturdy math flashcards that could be reused by subsequent classes.

Third, community partners in many case districts offered supplementary learning experiences that built self-efficacy and skills applicable to future academic and career contexts. In Riverside School District, an extension campus of the community college offered leadership training opportunities to local high school students. In several locations, civic organizations such as the Rotary Club held regional leadership seminars tied to small scholarships that covered travel and associated costs. In another case, a public agency developed a freshman seminar course for $9^{\text {th }}$ grade students, exposing them to career planning and basic life skills such as financial management. This program was adopted by the district and was run as part of the regular curriculum, demonstrating a deep level of trust and integration between the school and the community organization. Although these experiences may seem peripheral to college preparation, particularly for low-income students, they can provide exposure to new places, new ideas, and new social networks, expanding students' imagination for future academic and professional opportunities, and contributing to self-confidence needed to function within new and different environments.

Fourth, many students in our case districts, and particularly students from underrepresented groups, are often part of social networks connected to particular language groups or religious communities. Several school administrators and education activists discussed ways that these informal networks and affiliations can be used to reinforce the importance of academic focus generally, or to draw attention to particular school and district areas of emphasis, such as family reading time. When we asked Bernice, a school counselor (who was African American) why 
churches were a good avenue for disseminating messages from schools, she described how difficult it is to reach some of the students most in need of help:

Because a lot of your...students who are not very aware are your minorities. And for me, if we can get other adults involved, to know what's going on, they can help us spread the word. And if they don't come here for an after-school [activity], some of them will go to church. Or even if they don't go to church, there will be people who are close enough to them who do go who can help spread the word.

Thus, harnessing the natural proclivity of social networks to spread information may be one important way that schools can distribute information and encourage academic focus.

\section{College Information and Advising}

With regard to college information and advising, Joyce, a college access organization employee was explicit about this challenge, stating: These are...the higher risk kids. Not all of them in the program, but a lot of them... when I call them in one-on-one you could tell they didn't have a real perspective on the world after high school. Many students from lowincome families come to the end of high school either with unrealistic expectations or no expectations for what they will do after graduation. Although teachers and school counselors are most often the first line of information (Griffin, Hutchins, \& Meece, 2010), the volume of their responsibilities and number of students they serve can reduce the depth of individual student attention, despite their best efforts. In our case districts community partners augmented the work of school personnel in this area in two ways: by providing college information and by providing college advising.

At most college and universities students are required to fill out a Free Application for Federal Student Aid (FAFSA) form, whether they are seeking financial help or not. Low-income students whose parents are not familiar with the college-going process may not understand the importance of this document in the application and financial aid process. As a result, a wide variety of organizations in our case districts helped students complete the FAFSA, including religious groups, 4-H coordinators, public social services agencies, local college access providers, and local civic and special interest organizations. Some districts held a "college night" (either independently or in cooperation with a local or state organization) where students and families could receive help with this and other forms. Two of the districts participated in "Super Saturday" events, partnering with state education agencies and other school districts to complete requisite forms.

Low-income and first generation students often do not understand the many scholarships, grants, and loan options available, nor have they been informed about other requirements and processes, such as standardized test preparation and application timelines (Cabrera \& La Nasa, 2001). In these functions college access provider organizations were especially adept, though by no means were they the only channels through which students received assistance. Many of the case study school districts participated in the federal GEAR-UP grant program that provides academic and college entry assistance to an entire academic cohort as they progress from eighth through twelfth grades. Other districts had local or regional access organizations, some of which focused on a small group of qualifying (usually by income level) students who received intervention services throughout their high school careers. Other programs, such as the Career Coaches (a locallybased advisement program funded and organized through Virginia's community college system), offered help to any student, regardless of socioeconomic background.

Second, community partners advised students about their college and career options, both expanding awareness and delivering sober assessments of possible choices. Advising came about most often either as part of the organization's mission (such as Career Coaches and other access organizations) or through frequent contact that led to trusting relationships (such as faith-based organizations, certain social services organizations, or special interest groups). Often, these roles and relationships gave community partners a voice that was more extensive or more intensive than school personnel could provide. Wanda, who works for a state-based social services agency, described a situation where her level of intervention exceeded what school personnel were willing to give:

We had a student that had received a full ride last year to a college and the parent had no idea that it was a full ride. So on the last hour that that scholarship was due the child came to me and said, "[Wanda], I'm not going to be able to do the scholarship." And I said, "Why?" and he said, "Well, my mom truly doesn't understand and she's looking at the numbers and she's thinking that she has to come up with all of this money." So, I took the child home and I sat and talked to the mom.... And she was very, very happy that someone came out to explain it to her. When asked if anyone from the school had tried to assist this student, Wanda replied: 
To be honest, no one. ... We just can't sit back and say, "Ok the parents are not signing the papers." We have to go outside of the box and find out what's going on. Why didn't this parent do this? But the school is not going to go outside of the box. There are very few teachers that choose to go outside of the box. Other teachers are like "Ok, mom didn't come in so she doesn't care." I often preach to the teachers that it's not that the parents do not care it's that they don't know how or know what to do.

From our interviews we know that in many instances school personnel did "go outside of the box", to use Wanda's expression, yet in other contexts they may have felt limited by their formal roles or may simply have been unaware of the full circumstances students face. In such instances, for students or families to have more than one point of contact and advisement creates a back-up system that can ensure that a crucial opportunity is not missed, as occurred in this case.

\section{Socialization and Aspiration Experiences}

Although some students do reach the end of their high school career without forming a post-graduation plan, many others develop interests and aspirations for further education through exposure to new places, new ideas, and education and career opportunities offered through community partnerships of two types: Special events and positive influences.

Special events. Particularly for students in isolated areas exposure to an array of cultural centers and activities, such as museums, plays, and art galleries, and natural and built environments, such as botanical gardens, historical sites, state parks, and urban areas, can be at first bewildering. However, these experiences can also inspire students to take an interest in new ideas, cultures, foods, places, and forms of expression. The connection between a broadened cultural palette and college-going may seem distant. Yet an expanded view and appreciation of various cultural art forms, modes of communication, music styles, and history allows students to understand and participate in diverse forms of expression creating opportunities for new perspectives of self and home culture. Questions about the nature of human existence, human purpose, and human ingenuity happen most persistently within the arts. Engaging in those conversations can draw students into new ways of thinking about and relating to the world regardless of their future place of residence. Beyond cultural aspirations, once students are exposed to new career and educational opportunities and the potential social and economic benefits that accompany them, they may have greater incentive to enroll in postsecondary education.

Typically, organizations with a consistent presence among students and within the schools (access organizations, 4-H, community education foundations, and many others) were most likely to offer trips to nearby businesses, cities, state and national parks, historical sites, and other sorts of guided cultural experiences. However, civic organizations, higher education institutions, and public agencies also sponsored trips to leadership seminars, regional or national writing or speech contests, or on-campus college introduction weekends for individuals or small groups. As well, traveling exhibitions, performance groups (music, theater, and others), or speakers were sponsored by local businesses or organizations to come to an area, providing a similar experience.

More directly, trips to colleges and college tours were an important staple in programs designed to inspire student achievement and college aspirations. Although some school districts such as Riverside had in place structured programs that included tours of nearby colleges and universities as early as seventh grade, in other districts these opportunities originated either from in-school sub-groups (clubs, advising groups, organizations), were arranged per-student, or were delivered by or through a variety of community organizations. Particularly for students in geographically isolated areas, a visit to a college campus helped them begin to imagine themselves in the role of a college student. Researchers have found these experiences to be particularly potent for students of historically underrepresented groups (Attinasi, 1989). Eating in a dining hall, touring dormitories and classrooms, walking among students on the quad are all activities to help make college life seem normal and accessible for students who may never have set foot on a college campus before. Even for low-income students in relative geographic proximity to a college or university, lack of transportation or general timidity towards a college campus may have kept them from attending sporting events, concerts, or educational experiences hosted for high school students that might otherwise have delivered this initial exposure. Michelle, a 4-H director in Western District, reflected on a student who particularly benefitted from this experience: And in fact, there's one child that didn't think he was going to college, and I just heard he's getting $A$ 's and $B$ 's at [college]. And until we started going to colleges, he wasn't planning to go to college at all. It was a shame because he was, he had a lot going for him, he was very personable, but he needed to get to college, he 
needed to see that there were other things out there and that he had what it takes to get there.

Positive influences. Tours and cultural events provide direct exposure but make an indirect case to students that their future plans should include some sort of postsecondary education. Directly, community partners of all types served as mentors and models, in many cases offering specific encouragement to students who may not have considered higher education before. Researchers note that even with the presence of college-going resources and opportunities, students often need this sort of direct injunction to personally believe that higher education is for them. In a study of MexicanAmerican young people, Attinasi (1989) noted that peer modeling by siblings, friends, and acquaintances who go to college and speak positively about their experiences significantly impacted high school student's thinking about their own future plans. Similarly, within our study faith-based organizations were often places where this social influence was passed on through annual recognition of and celebration of high school and college graduates, through religious mentors who regularly checked grades and provided accountability for academic performance, and through individuals who directly encouraged students to consider postsecondary education. James, a pastor in Heritage School District described this function in his congregation:

Publicly we lift them up and we celebrate their success and we wish them well in their further endeavors and encourage [others in thinking that] college or furthering their education will be a part of it. I think it's definitely encouraged, embraced. I haven't seen anybody that says "well, just stay on the farm - this is your life here." I think there is a general sense that we want you to go off and do better and to get an education.

Other groups, such as community education foundations, used the peer influence of recent graduates returning home from college during school breaks to talk about their experiences and encourage the rising classes to consider their college options. Influence from religious groups and other organizations can come in the form of encouragement to use school resources and seek out the information needed to advance toward college. A woman who works with the youth in her church discussed how she sends her students to the guidance counselors for help in addition to the assistance she provides as a former teacher.

Widening the circle, a common form of partnering that can lead to academic and postsecondary aspirations is to invite local professionals, business owners, and other local leaders to discuss not only the details of their careers, but to explain the steps they took to reach their current positions. In one school Susan, a guidance counselor, polled students on careers of interest and then invited community professionals in, to great effect:

So they come in and say "It's really great to be a doctor but this is how many years of college it took, and this is how dedicated I had to be even in high school". She was really good, the teacher that kind of helped us develop the class, in laying out some good questions for these people so they could say "These are some class that you might want to take in high school", you know, "don't take the easy road". Or "These are some clubs that might be of interest to you" or "It's really important for you to be involved in things outside of the school".

Clearly, not only were career pathways described for students, but also the sorts of courses and extracurricular activities necessary to set up future access to higher education. School personnel also discussed inviting in speakers from outside organizations and colleges and universities to talk about career and educational opportunities that students might not otherwise experience or understand. In one district the community college sponsored a program that targeted high risk African-American males by bringing in speakers who came from similar backgrounds and were able to relate to students in ways that teachers could not.

\section{The Formal and Informal Economy of Support}

The final two ways in which community partners support the college aspirations of local students, and in particular low-income students, are less concrete and can be more difficult to identify from any single action or event. However, in several of the school districts the accumulated and combined efforts and expectations of school and community stakeholders did create a palpable sense that education was a high priority and was supported across the community. This positive momentum was evident in the language community members and educators used when referencing education and from the efforts taken to actively support schools and students materially, financially, interpersonally, and programmatically.

In the hierarchy of student support systems, parents are most centrally and broadly responsible. Schools take a secondary place based on educational mission and mandates, and the community can act as a cohesive force, a safety net, and a resource to parents and schools. However, in areas with a low total population and a high percentage of low-income 
residents, some parents may be unable to provide for the basic physical, psychological, and developmental needs of their children. Students bring deficits of preparation, development, and support to school, pressing the education system and the local community into roles typically occupied by parents. Throughout the study we heard how local school teachers and administrators gave of their own time and resources to quietly meet student needs for clothing, school supplies, uniforms, trips, and a myriad of other minor expenses, in addition to offering support, encouragement, and a listening ear to distressed or struggling students.

School personnel are not alone in these acts of self-sacrifice: the close and informal social circles that typify rural life in our case districts carried word of needs quickly, often to persons in community organizations. In some cases these organizations were specifically outfitted to meet such needs, but in many cases they also supplemented the efforts of parents and schools. At the heart of this behavior, and a theme echoed through all six of our case districts in different ways and to different degrees, was a strong sense of ownership and responsibility for students whose circumstances have dramatically disadvantaged them through no fault of their own. When asked to identify the key elements to students' success in this environment, Jennifer, a public agency-based college access provider, described the community as an essential part, reflective of comments offered by many study participants:

It's the community support I think by far. It's the encouragement of the community and many of us might see just like this one child, I'd give him money out of my kid's account if I thought that would help him, and there are a lot of people that think that way. They sacrifice... to [help] this kid who needs the money to take the SAT or needs money for a college application. There's a boat load of us that see the community support and the community need and we're going to give to whomever. And it's not just the agency people: its people within the church, its people within the community.... I think that's what makes the difference. It's the small community spirit.

Significantly, this participant linked community intervention not only to student success, but specifically to combined community efforts that remove barriers to college-going in addition to meeting basic student needs.

\section{Community Commitment to the Value of Higher Education}

Jennifer's account of multiple points of local support describes community altruism and concern for the welfare of local young people. However, it also suggests a critical mass of community members - both individuals and organizations - committed to ensuring that students have the resources necessary to succeed academically and to pursue postsecondary education, as a reflection of shared schoolcommunity goals. Amber, a school administrator in Greenfield described the partnership of schools and community groups in terms of sharing a common purpose, rather than seeing the work of the school as an isolated enterprise:

I think they [community partnerships] are a very important part of it because...I think they're really supporting the common vision and mission of the school division. ...I think it's important that the student sees that the whole community supports the mission of the school, and it's not just the school's mission, it's the community's mission.

Amber's statement identifies two of the most important reasons for school-community partnerships in small rural areas: functionally, partnerships provide resources that reinforce the educational foci of the district through experiences outside the classroom and enable students to pursue postsecondary goals through financial and logistical support. Symbolically, partnerships tell students that educational achievement is a value spanning the entire community, and not only within the walls of the school. Partnerships convey expectations that educational degree attainment of some type is possible for all young people. And, partnerships can convey a community vision for the type of place citizens are working to create.

Timothy, the director of a community college extension center, described the necessity of the whole community moving in a similar direction and focusing whatever limited resources are available toward a common goal. Paraphrasing entrepreneurship guru, Ernesto Sirolli, he said, the future of every community lies in capturing the energy, imagination, the passion of its people. Reflecting then on his own rural location, Timothy demurred: I don't represent us as being all of the way there, but I do represent us as a community that has those kinds of conversations, and I would say that that's different than many. Rather than looking outward for assistance from the state or from a major corporation, Timothy asserted that the focus must be on maximizing local resources and believing that the solution is primarily internal: We can't always 
depend on somebody to come here. We've got to build the capacity of people from within.

\section{Conclusions}

Study results show the rich confluence of community resources that can, with vision and coordination, significantly aid all local students, including those from low-income families. This range of supports supplements the work of school personnel by reinforcing educational goals and programs, building students' self-efficacy and vocational imagination through connections to cultural, historical, natural, and other types of area resources, and by providing a safety net for students in need of additional assistance or encouragement. The most successful of our case study districts demonstrated a broad-based commitment to the value of school success and postsecondary preparation access for the betterment of the individual student and for the prosperity of the area. Although all six case districts were making positive strides toward educational improvement, districts were at different points with regard to establishing a widespread commitment to the value of education as an important local goal reflected in the types of cooperation between school personnel, local public officials, the business community, and the non-profit community. In the higher achieving school districts, stakeholders in a variety of political, educational, and community activist roles described high quality schools as a key to the success of the area and that required a total community commitment. The reward is a generation of young people prepared to contribute to society (whether in their community or another) and a school system that may be a selling point to business owners, developers, and professionals who may be attracted to the area as a result.

\section{Limitations and Future Directions of Inquiry}

The methodology and findings of this study present three limitations that also represent areas for future research. The locally grounded nature of case study research provides rich context and insight into participant experiences and sense making. However, findings are primarily indicative of the study area and are only logically generalizable to other locations and populations. Studies of college aspirations and school-community partnerships in other rural contexts (in the United States and elsewhere) may add new perspectives to the discussion begun here.

Second, our research efforts focused primarily on the impact of formal structures and mechanisms within rural communities. As a result nonparticipants (including many low-income residents, elderly residents, and residents for whom English is a second language) in formal educational or civic structures were largely left out of our study. We recognize the value of their perspectives and the informal natural helping networks (Libertoff, 1980) that may be important aspects of their information and resource gathering. Similar future studies should be attentive to non-structural avenues through which low-income residents build individual capacity, share resources, and develop future plans.

Third, our focus on community structures and the people who run them left out a very important constituent group: students themselves. Although excluding students was a strategic decision and not an omission, we also recognize that the impact of school-community partnerships needs to be considered from the student perspective if we are to fully understand the role of partnerships in rural areas.

Finally, the position of education in rural contexts has experienced a critical turn in recent years, often focusing on the damage done rather than the opportunities afforded by formal schooling (Carr \& Kefalas, 2009; Corbett, 2007; Sherman \& Sage, 2011, among many others). This study joins other recent efforts (Petrin, Schafft, \& Meece, 2012) that acknowledge the validity of these critiques and yet empirically demonstrate ways in which critical studies may deliver overly generalized results. We encourage researchers and practitioners to stay current in this ongoing conversation and consider what sorts of studies will offer thoughtful, robust, and actionable analysis that acknowledges these meaningful critiques.

\section{References}

Apostal, R., \& Bilden, J. (1991). Educational and occupational aspirations of rural high school students. Journal of Career Development, 18(2), 153-160.

Attinasi, L. C. Jr. (1989). Getting in: Mexican Americans' perceptions of university attendance and implications for freshman year persistence. Journal of Higher Education, 60, 247-277.

Barley, Z A., \& Beesley, A.D. (2007). Rural school success: What can we learn? Journal of Research in Rural Education, 22(1), 1-16. 
Battistich, V., Solomon, D., Kim, D., Watson, M. \& Schaps, E. (1995). Schools as communities, poverty levels of student populations, and students' attitudes, motives, and performance: A multilevel analysis. American Educational Research Journal, 32, 627-658.

Bauch, P. A. (2001). School-community partnerships in rural schools: Leadership, renewal, and a sense of place. Peabody Journal of Education, 76(2), 2004-221.

Beaulieu, L., \& Israel, G. D. (2005). It's more than just schools: How families and communities promote student achievement. In L. Beaulieu \& R. Gibbs (Eds.), The role of education: Promoting the economic and social vitality of rural America (pp. 44-55). Mississippi State University, MS: Southern Rural Development Center.

Cabrera, A. F., \& La Nasa, S. M. (2001). On the path to college: Three critical tasks facing America's disadvantaged. Research in Higher Education, 42(2), 119-149.

Carr P. J. \& Kefalas, M. J. (2009). Hollowing out the middle: The rural brain drain and what it means for America. Boston, MA: Beacon Press.

Chance, P. L., \& Segura, S. N. (2009). A rural high school's collaborative approach to school improvement. Journal of Research in Rural Education, 24(5). Retrieved from http://jrre.psu.edu/articles/24-5.pdf

Chance, E. W., Work, J., \& Larchick, R. (1992). Creating an effective rural school district: $A$ case study. Paper presented at the National Council of Professors of Educational Administration National Conference. Terre Haute, Indiana, August, 1992.

Chenoweth, E., \& Galliher, R. V. (2004). Factors influencing college aspirations of rural West Virginia high school students. Journal of Research in Rural Education, 19(2), 1-14.

Combs, L., \& Bailey, G. (1992). Exemplary schoolcommunity partnerships: Successful programs. Rural Educator, 13(3), 8-13.

Corbett, M. (2007). Learning to leave: The irony of schooling in a coastal community. Black Point, Nova Scotia: Fernwood.

Crosnoe, R. (2004). Social capital and the interplay of families and schools. Journal of Marriage and Family, 66(2), 267-280. DOI: 10.1111/j.17413737.2004.00019.x

Donaldson, G. A. (1986). Do you need to leave home to grow up? The rural adolescent's dilemma. Journal of Research in Rural Education, 3(3), 121-125.
Decker, L. E. \& Decker, V. A. (2003). Home, school, and community partnerships. Lanham, MD: Scarecrow Press.

Demi, M A., Coleman-Jensen, A., \& Snyder, A. R. (2010). The rural context and post-secondary school enrollment: An ecological systems approach. Journal of Research in Rural Education, 25(7), 2-26.

Gibbs, R. M. \& Cromartie, J. B. (1994). Rural youth outmigration: How big is the problem and for whom? Rural Development Perspectives, 10(1), 9-16.

Griffin, D., Hutchins, B. C., \& Meece, J. L. (2010). Where do rural high school students go to find information about their futures? Journal of Counseling \& Development, 89(2), 172-181.

Harmon, H. L., \& Schafft, K. (2009). Rural school leadership for collaborative community development. The Rural Educator, 30(3), 4-9.

Howley, C. (1996). Compounding disadvantage: Consolidation and the effects of school and district size on student achievement in West Virginia. Journal of Research in Rural Education, 12, 25-32.

Irvin, M. J., Farmer, T. W., Leung, M-C, Thompson, J. H., \& Hutchins, B. C. (2010). School, community, and church activities: Relationship to academic achievement of low-income African American early adolescents in the rural deep south. Journal of Research in Rural Education, 25(4), 1-21.

Israel, G. D., Beaulieu, L. J., \& Hartless, G. (2001). The influence of family and community social capital on educational achievement. Rural Sociology, 66(1), 43-68.

Isernhagen, J. C. (2010). TeamMates: Providing emotional and academic support in rural schools. Rural Educator, 32(1), 29-36.

Kelly, U. A. (2009). Learning to lose: Rurality, transience, and belonging (a companion to Michael Corbett). Journal of Research in Rural Education, 24(11). Retrieved from http://jrre.psu.edu/articles/24-11.pdf

Khattri, N., Riley, K.W., \& Kane, M. B. (1997). Students at risk in poor, rural areas: A review of the research. Journal of Research in Rural Education, 13, 79-100.

Lee, V. E., \& Burkam, D. T. (2003). Dropping out of high school: The role of school organization and structure. American Educational Research Journal, 40(2), 353-393.

Lerner, R.M. (1995). America's youth in crisis: Challenges and options for programs and policies. Thousand Oaks, CA: Sage. 
Libertoff, K. (1980). Natural helping networks in rural youth and family services. Journal of Rural Community Psychology, 1(1), 4-18.

Lyson, T. A. (2002). What does a school mean to a community? Assessing the social economic benefits of schools to rural villages in New York. Journal of Research in Rural Education, 17(3), 131-137.

McDonough, P. M., Gildersleeve, R. E., \& Jarsky, K. M. (2010). The golden cage of rural college access: How higher education can respond to the rural Life. In K. A. Schafft \& A.Y. Jackson (Eds.), Rural education for the twenty-first Century: Identity, place, and community in a globalizing world (pp. 191-209). University Park, PA: Penn State Press.

McGrath, D. J., Swisher, R. R., Elder Jr., G. H., \& Conger, R. D. (2001). Breaking new ground: Diverse routes to college in rural America. Rural Sociology, 66(2), 244-267.

Petrin, R., Schafft, K., \& Meece, J. (2012). Educational sorting and residential aspirations among rural high school students: What are the contributions of schools and educators to the rural brain drain? Paper presented at the American Educational Research Association annual meeting, April 2012, Vancouver, BC.

Regnerus, M. D., \& Elder Jr., G. H. (2003). Staying on track in school: Religious influences in highand low-risk settings. Journal for the Scientific Study of Religion, 42(4), 633-649.
Roscigno, V. J., \& Crowley, M. L. (2001). Rurality, institutional disadvantage, and achievement/attainment. Rural Sociology, 66(2), 268-292.

Sanders, M. G. (2006). Building school-community partnerships: Collaboration for student success. Thousand Oaks, CA: Corwin.

Sherman. J. \& Sage, R. (2011). Sending off all your good treasures: Rural schools, brain-drain, and community survival in the wake of economic collapse. Journal of Research in Rural Education, 26(11). Retrieved from http://jrre.psu.edu/articles/26-11.pdf.

Stanton-Salazar, R. D., \& Spina, S. U. (2003). Informal mentors and role models in the lives of urban Mexican-origin adolscents. Anthropology \& Education Quarterly, 34(3), 231-254.

Stockard, J., \& M. Mayberry. (1992). Effective educational environments. Newbury Park, CA: Corwin.

Wright, C. J. (2012). Becoming to remain: Community college students and post-secondary pursuits in central Appalachia. Journal of Research in Rural Education, 27(6). Retrieved from http://jrre./psu.edu/articles/27-6.pdf

Wright, K., Stegelin, D. A., \& Hartle, L. (2007). Building family, school, and community partnerships ( $3^{\text {rd }}$ ed.). Upper Saddle River, NJ: Pearson.

\section{About the Authors:}

Nathan F. Alleman is an Assistant Professor in Educational Administration in the Higher Education and Student Affairs program at Baylor University, Waco, TX 76798. Nathan_Alleman@Baylor.edu

L. Neal Holly is a Research and Policy Analyst with the West Virginia Higher Education Policy Commission in Charleston, West Virginia. nholly@ hepc.wvnet.edu 